\title{
Dinitrophenol-induced ATPase of rat-liver mitochondria
}

Citation for published version (APA):

Hemker, H. C., \& Hülsmann, W. C. (1961). Dinitrophenol-induced ATPase of rat-liver mitochondria. Biochimica et Biophysica Acta. Mucoproteins and Mucopolysaccharides, 48(1), 221-223. https://doi.org/10.1016/0006-3002(61)90784-3

Document status and date:

Published: 18/03/1961

DOI:

10.1016/0006-3002(61)90784-3

Document Version:

Publisher's PDF, also known as Version of record

\section{Please check the document version of this publication:}

- A submitted manuscript is the version of the article upon submission and before peer-review. There can be important differences between the submitted version and the official published version of record.

People interested in the research are advised to contact the author for the final version of the publication, or visit the DOI to the publisher's website.

- The final author version and the galley proof are versions of the publication after peer review.

- The final published version features the final layout of the paper including the volume, issue and page numbers.

Link to publication

\footnotetext{
General rights rights.

- You may freely distribute the URL identifying the publication in the public portal. please follow below link for the End User Agreement:

www.umlib.nl/taverne-license

Take down policy

If you believe that this document breaches copyright please contact us at:

repository@maastrichtuniversity.nl

providing details and we will investigate your claim.
}

Copyright and moral rights for the publications made accessible in the public portal are retained by the authors and/or other copyright owners and it is a condition of accessing publications that users recognise and abide by the legal requirements associated with these

- Users may download and print one copy of any publication from the public portal for the purpose of private study or research.

- You may not further distribute the material or use it for any profit-making activity or commercial gain

If the publication is distributed under the terms of Article $25 \mathrm{fa}$ of the Dutch Copyright Act, indicated by the "Taverne" license above, 


\section{Dinitrophenol-induced ATPase of rat-liver mitochondria}

MYERS AND SLATER ${ }^{1}$ found that with increasing concentrations of 2,4-dinitrophenol the aptimum $\mathrm{pH}$ of the dinitrophenol-induced ATPase of rat-liver mitochondria moved to higher $\mathrm{pH}$ 's. From the form of the $\mathrm{pH}$-activity curves with different concentrations of 2,4-dinitrophenol, these authors drew the conclusion that three enzyme systems with $\mathrm{pH}$ optima at $6.3,7.4$ and 8.5 , respectively, were present in the mitochondria, the 6.3 enzyme being stimulated by low concentrations of dinitrophenol (and inhibited by higher) while higher concentrations were necessary to induce activity in the 8.5 enzyme.

The alternative explanation of these results, namely that the decreasing activity of dinitrophenol with increasing $\mathrm{pH}$ was due to the fact that the undissociated phenol is the active form, was rejected because at $\mathrm{pH} 7.4$-nitrophenol and 2,4-dinitrophenol have similar uncoupling activity, whereas the concentrations of the undissociated phenols differ by a factor of about I, ooo at this $\mathrm{pH}(\mathrm{pK}$ of 2,4-dinitrophenol, 4.I; of $p$-nitrophenol, 7.2). In agreement with this conclusion, PARKER ${ }^{2}$ reported that at $\mathrm{pH} 6.8$ the most potent uncouplers of oxidative phosphorylation in rat-liver mitochondria are those phenols with the lowest $\mathrm{p} K$ 's.

GLADTKE AND LIss ${ }^{3}$, on the other hand, drew attention to cases where there was a poor correlation between $\mathrm{p} K$ and the uncoupling activity. They, and independently HÜLSMAN ${ }^{4}$, introduced a new factor into the consideration of the relative effectiveness of substituted phenols as uncoupling agents, namely the lipid solubility.

Myers AND Slater ${ }^{1}$, PARKer $^{2}$ and Hülsmann ${ }^{4}$ have drawn attention to the inhibition of the dinitrophenol-induced ATPase by higher concentrations of dinitrophenol. The concentration $\left(C_{\text {opt }}\right)$ giving maximum ATPase has been used in the present

TABLE I

COMPARISON OF OPTIMAL CONCENTRATIONS OF DIFFERENT NITROPHENOLS AT VARIOUS PH'S FOR INDUCTION OF ATPASE ACTIVITY OF RAT-LIVER MITOCHONDRIA

ATPase activity was determined as described by Myers AND SLATER ${ }^{1}$. The $\mathrm{p} K$ and $\mathrm{p} Q$ values were determined spectrophotometrically.

\begin{tabular}{|c|c|c|c|c|c|c|c|}
\hline \multirow{2}{*}{ Compound } & \multirow{2}{*}{$p K$} & \multirow{2}{*}{$p Q^{*}$} & \multicolumn{5}{|c|}{$p C_{o p t} t^{\star \star}$ at $p H^{\prime} s$} \\
\hline & & & 5 & 6 & 7 & 8 & 9 \\
\hline p-nitrophenol & 7.2 & +0.45 & $3 \cdot 30$ & $3 \cdot 37$ & $3 \cdot 5^{I}$ & $3 \cdot 39$ & - \\
\hline 2,6-dinitrophenol & 3.7 & -2.35 & $4 \cdot 77$ & 4.22 & 3.68 & 3.12 & - \\
\hline 2,6-dinitro-3,4-dimethylphenol & & & 4.92 & $4 \cdot 5 \mathrm{I}$ & $4 \cdot 36$ & 3.95 & 3.60 \\
\hline 2,6-dinitro-4-isobutylphenol & $4 \cdot 3$ & -3.54 & $5 \cdot 16$ & 4.88 & $4 \cdot 71$ & $4 \cdot 4^{8}$ & 4.26 \\
\hline 2,6-dinitro-4-isoamylphenol & $4 \cdot \mathrm{I}$ & -4.15 & $5 \cdot 55$ & $5 \cdot 4^{2}$ & $5 \cdot 18$ & 4.92 & $4 \cdot 7 \mathrm{I}$ \\
\hline 2,6-dinitro-4-iso-octylphenol & 4.05 & $-4 \cdot 75$ & 6.08 & 5.89 & 5.64 & $5 \cdot 4^{\mathrm{I}}$ & $5 \cdot 24$ \\
\hline
\end{tabular}

$$
{ }^{\star} p Q=-\log _{10} \frac{\text { concentration of undissociated phenol in xylene }}{\text { concentration of undissociated phenol in water }}
$$

For the dinitrophenols at $\mathrm{pH}$ 's $>5$,

$$
\begin{aligned}
& \mathrm{p} Q=\mathrm{p} K-\mathrm{pH}-\log _{10} \frac{\text { concentration of undissociated phenol in xylene }}{\text { concentration of total phenol in water }} \\
& { }_{\star \star \star \star} \mathrm{p} C_{\mathrm{opt}}=-\log _{10} C_{\mathrm{opt}} .
\end{aligned}
$$

Abbreviation: ATP, adenosine triphosphate. 
study for a quantitative study of the relationship between the lipid solubility and the uncoupling activity of alkyl-substituted nitrophenol compounds.

The maximum ATPase was found to be the same for 2,6-dinitrophenol and a series of alkyl-substituted 2,6-dinitrophenols. At a fixed $\mathrm{pH}, C_{\text {opt }}$ was found to decrease with increasing lipophilic character of the compound. For each of the nitrophenols listed in Table I, except p-nitrophenol, $C_{\text {opt }}$ increased with increasing $\mathrm{pH}$, there being a linear relationship between $\mathrm{pH}$ and $\mathrm{p} C_{\mathrm{opt}}$. In the case of $p$-nitrophenol, which differs from the dinitrophenols studied by virtue of its much higher $\mathrm{p} K$ and lower lipid solubility, $\mathrm{p} C_{\text {opt }}$ was largely independent of $\mathrm{pH}$ between 5 and 7 . Above $\mathrm{pH} 8$, it followed the same relationship with $\mathrm{pH}$ as the dinitrophenols.

These results can be explained on the assumption that the undissociated phenol must be taken up into the mitochondria before it induces ATPase activity. The concentration of nitrophenol in the lipid phase $\left(C_{\mathrm{L}}\right)$ will be governed by the concentration in the aqueous phase $\left(C_{\mathrm{aq}}\right)$, the $\mathrm{pH}$ of the reaction medium and the $\mathrm{p} K$ and $\mathrm{p} Q$ (see Table I) of the nitrophenol. When $\mathrm{p} K$ is much less than the $\mathrm{pH}$, as is the case with all the dinitrophenols investigated,

$$
\mathrm{p} C_{\mathrm{L}}=\mathrm{p} C_{\mathrm{aq}}-\mathrm{p} K+\mathrm{p} Q+\mathrm{pH}
$$

In Table II are given the values of $\mathrm{p} C_{\mathrm{L}}$ when $\mathrm{p} C_{\mathrm{aq}}$ equals $\mathrm{p} C_{\text {opt }}$ given in Table I (it is assumed that the partition coefficient between water and mitochondrial lipid is the same as that between water and xylene). From this table it can be concluded that

(i), when at a particular $\mathrm{pH}$ the ATPase is maximally stimulated, the concentration of the phenol in the lipid phase $\left(C_{\mathrm{L}}\right)$ is independent of the degree of lipophilicity $(\mathrm{p} Q)$ of the compound;

(ii), $\mathrm{p} C_{\mathrm{L} . o p t}$ increased with increasing $\mathrm{pH}$, according to the equation $\mathrm{p} C_{\mathrm{L} . \mathrm{opt}}=$ - I.49 $+0.76 \mathrm{pH}$, i.e. $C_{\mathrm{L}}$ necessary for maximal ATPase is less the higher the $\mathrm{pH}$.

Although these results do not prove that it is the undissociated phenol which reacts in the mitochondria, it is clear that the concentration of the undissociated

TABLE II

CALCULATION FROM DATA IN TABLE I OF CONCENTRATION IN MITOCHONDRIAL LIPID $\left(C_{\mathrm{L}}\right)$ OF DIFFERENT NITROPHENOLS AT VARIOUS $\mathrm{pH}$ 'S

$$
\mathrm{p} C_{\mathrm{L}}=\mathrm{p} C_{\mathrm{opt}}-\mathrm{p} K+\mathrm{p} Q+\mathrm{pH}
$$

\begin{tabular}{|c|c|c|c|c|c|c|c|}
\hline \multirow{2}{*}{ Compound } & \multirow{2}{*}{$p K$} & \multirow{2}{*}{$p Q$} & \multicolumn{5}{|c|}{$p C_{L}$ at $p H$ 's } \\
\hline & & & 5 & 6 & 7 & 8 & 9 \\
\hline$p$-nitrophenol ${ }^{\star}$ & 7.2 & +0.45 & $3 \cdot 55$ & 3.62 & 4.06 & 4.62 & - \\
\hline 2,4 -dinitrophenol ${ }^{\star \star}$ & $4 \cdot I$ & -2.06 & $3.6 \mathrm{I}$ & 4.06 & $4 \cdot 5^{2}$ & 4.96 & - \\
\hline 2,6-dinitrophenol & 3.7 & -2.35 & $3 \cdot 72$ & $4 \cdot 17$ & 4.63 & 5.07 & 一 \\
\hline 2,6-dinitro-3,4-dimethylplienol & & & 2.48 & 3.07 & 3.82 & $4 \cdot 5^{\mathrm{I}}$ & 5.16 \\
\hline 2,6-dinitro-4-isobutylphenol & $4 \cdot 3$ & $-3 \cdot 54$ & 2.33 & 3.05 & 3.88 & 4.65 & $5 \cdot 43$ \\
\hline 2,6-dinitro-4-isoamylphenol & 4.1 & -4.15 & 2.30 & 3.04 & 3.93 & 4.67 & $5 \cdot 56$ \\
\hline 2,6-dinitro-4-iso-octylphenol & 4.05 & $-4 \cdot 75$ & 2.28 & 3.09 & 3.84 & $4.6 \mathrm{I}$ & $5 \cdot 44$ \\
\hline
\end{tabular}

* In this case, the simple expression is not applicable, since $\mathrm{pH}$ is not greater than $\mathrm{p} K$. $\mathrm{p} C_{\mathrm{L}}$ was calculated from the expression $\mathrm{p} C_{\mathrm{L}}=\mathrm{p} C_{\text {opt }}+\mathrm{p} Q+\mathrm{pH}+\log \left(K+\left[\mathrm{H}^{+}\right]\right)$.

${ }^{* *}$ This compound was not so extensively investigated as 2,6-dinitrophenol, but no significant difference was found between the values of $\mathrm{p} C_{\mathrm{opt}}$ for the two compounds. For purposes of calculation, it has been assumed that they were identical.

${ }^{\star \star \star} \mathrm{p} K-\mathrm{p} Q=7 \cdot 44$. 
phenol in the medium determines the degree of uncoupling by a particular dinitrophenol and that this is the explanation of the decreasing degree of uncoupling with increasing $\mathrm{pH}$. In comparing different nitrophenols, two factors have to be considered - the $\mathrm{p} K$ and the lipid solubility. In a series of dinitrophenols which all have about the same $\mathrm{p} K$, it is the lipid solubility which determines the relative degree of uncoupling. When comparing $p$-nitrophenol with 2,4-dinitrophenol the difference in $\mathrm{p} K$ (3.I) is largely compensated in the other direction by the difference in $\mathrm{p} Q(2.55)$, so that the fact that around neutral $\mathrm{pH}$ the two compounds uncouple to about the same extent is purely coincidental.

From the above results, it follows that the $\mathrm{pH}$-activity curve of the dinitrophenolinduced ATPase at a fixed dinitrophenol concentration does not describe the effect of $\mathrm{pH}$ on the enzyme system. It is necessary to determine the relationship between $\mathrm{pH}$ and the maximum activity measured at the $C_{\text {opt }}$ corresponding to each $\mathrm{pH}$. In this way, a single maximum at $\mathrm{pH} 6.9$ was found for 2,4-dinitrophenol and 2,6dinitro-4-isoamylphenol.

Thus, $\mathrm{pH}$-activity curves do not give any evidence of the presence in rat-liver mitochondria of more than one dinitrophenol-induced ATPase.

Preliminary studies suggest that at pH 7.2 the optimum found in the activityconcentration curve with 2,4-dinitrophenol in reality consists of two peaks close to one another. PENNIALL ${ }^{5}$ has recently reported that soluble extracts of mitochondrial acetone powders exhibit multiphase curves of ATPase response to dinitrophenol at $\mathrm{pH} 8.5$, when tested in the absence of added salts.

The authors wish to thank Prof. E. C. Slater for his interest and constructive criticism and Miss M. VAN UFFELEN for skilful technical assistance.

This investigation was supported in part by research grant RG-6569 from the U.S. Public Health Service.

\section{Laboratory of Physiological Chemistry, University of Amsterdam \\ H. C. HEMKER (The Netherlands) \\ W. C. HüLsmann}

1 D. K. Myers and E. C. Slater, Biochem. J., 67 (1957) 558, 572.

2 V. H. PARker, Biochem. J., 69 (1958) 306.

3 E. Gladtike and E. Liss, Biochem. Z., 33i (i 959).65.

4 W. C. HüLSMANN, Over het mechanisme van de ademhalingsketenphosphorylering, M.D. thesis, Klein Offset Drukkerij Poortpers, Amsterdam, 1958.

5 R. Penniall, Biochim. Biophys. Acta, 44 (I960) 395.

Received January I9th, I96I 